\title{
COMPOST PRODUCTION FROM SOME AGRICULTURAL WASTES
}

Dora, M.D. ${ }^{1}$; N.N. El- Hefnawy²; S.M. Ahmed ${ }^{3}$; Kh.M. Ghanem ${ }^{4}$ and

Ghada S. El-Sharkawy, ${ }^{4}$

1- Soils and Water Dept., Fac. Agric., Al- Azhar University, Cairo, Egypt.

2- Environ. Studies and Res. Inst., Minoufiya Univ., Sadat City, Egypt.

3- Microbiol. Dept., Soils, Water and Environ. Res. Inst.. Agric. Res. Center, Giza, Egypt.

4- Environ. and Bio-Agric. Dept., Fac. Agric., Al-Azhar Univ., Cairo, Egypt.

\begin{abstract}
The aim of this study is to investigate the prevailing physico-chemical changes and microbial structure during composting of agricultural wastes. Two kinds of crop residues (rice straw and cotton stalks) were selected with cattle dung to make nine mixtures. Some of these mixtures were mixed with natural amendments to investigate their influences on composting process and the end product. The composting process was allowed to continue up to 12 weeks. Results showed that all physical, chemical and biological properties of mixtures were strongly influenced by the type of raw wastes and natural additives. Where, $\mathrm{pH}$ and electrical conductivity $(E C)$ values were increased with increasing composting period. High concentrations of $\mathrm{NH}_{4}-\mathrm{N}$ were observed at the thermal phase and then decreased towards the end of composting, while the contents of $\mathrm{NO}_{3}-\mathrm{N}$ showed an opposite trend. In this respect, a gradual increase in total nitrogen was observed, while organic matter, organic carbon and $\mathrm{C} / \mathrm{N}$ ratio were significantly decreased as composting progressed. Decomposition rates of the organic matter increased and reached to its maximum values after the $4^{\text {th }}$ week. Meanwhile, application of natural amendments induced relatively high values of decomposition rates. Availability of both phosphorus and potassium were significantly increased throughout the decomposition period. Further improvements in the examined parameters were gained by application of the natural amendments and still more pronounced with EM addition. Salmonella and Shegilla counts dropped rapidly, being not detected at the end of composting. But a general increase in counts of phosphate dissolving bacteria throughout the composting process was observed especially in the amended treatments. Numbers of ammonifiers and nitrifying bacteria varied according to compost age, type of raw wastes as well as natural additives.

Keywords: Composting, Agricultural wastes, Rice straw, Cotton stalks, Natural amendments.
\end{abstract}

\section{INTRODUCTION}

It is well known that burning crop residues has harmful environmental effects and health costs through increasing the respiratory problems in the local population. It is currently estimated that over 30 million tons/year of agricultural wastes are generated in Egypt with rice straw exceeding 4 million tons and about 1.2 million tons annually from cotton stalks. In general, the major percent of these crop residues are not utilized (UNDP, 2005). In addition, the traditional methods of using crop residues and cattle dung are of low efficiency and deprive agricultural lands of needed organic matter and 
plant nutrients. In addition, such methods are a constant hazard to human and animal health and represent a major source of environmental pollution (ElShimi, 2005). However, the use of agricultural wastes as soil amendments on farmland instead of burning is an attractive alternative because it allows for some cost recovery, improves soil physical, chemical and biological properties and recycles the nutrients into the soil (Edwards, 2002).

Composting is an aerobic process by which organic wastes are decomposed through the activities of successive groups of microorganisms (Gajdos, 1992) and converted into organic manure rich in plant nutrients and humus (Sharma et al., 1999). It is an environmentally sound way to reduce organic wastes and produce either organic fertilizers or soil conditioners. Besides, the use of compost for plant nutrition in organic farming systems, it is also considered the cornerstone of nutrient resources for conserving the soil fertility.

Enriched compost is attained through management of the composting process by addition of microorganisms capable of tolerating and/or decomposing inhibitory compounds, and/or mixing with other substances that stimulates biological decomposition. Some researchers have reported the effect of natural amendments on composting process. Allam (2005) found that application of natural minerals such as rock phosphate and feldspar to the composted organic materials enhanced the decomposition rate throughout the composting period. This may be due to the availability of essential nutrients for the increased biological activity as it was explained by Gautam et al., (2009). Moreover, compost enrichment reduces nitrogen volatilization, increases the percentage of humic substances in the end product and releases some nutrients to be available for plants, especially phosphorus and potassium contents (Kaloosh, 1994; Estefanous, 2003; ElHaggar et al., 2004 and Ebrahim, 2006).

The objectives of this work are to monitor composting process of some agricultural residues combined in different ratios and enriched with some natural additives. The effects of such natural additives on composting process and the end product, as well as the changes in the microbial community structure during composting were also taken into consideration.

\section{MATERIALS AND METHODS}

\section{Compost preparation}

For compost preparation, two plant residues (rice straw and cotton stalks) and cattle dung were selected to make nine mixtures. Plant residues were air dried and chopped into small pieces $(3-5 \mathrm{~cm}$ length) while, the animal waste was used fresh. Some characteristics of these raw materials are presented in table (1). The materials of each pile were made homogenous by mixing them to give total weight about 200 kilograms for each pile and having $\mathrm{C} / \mathrm{N}$ ratio about 30:1. For decomposition, the mixtures were tilled in plastic containers having $(100 \times 100 \times 150) \mathrm{cm}(\mathrm{W} \times \mathrm{L} \times \mathrm{H})$, respectively. 


\section{Preparation of the composting mixtures in different proportions was as} follow:

1. Rice straw $(R S)+$ cattle dung $(C D)(1: 1)$ dry weight basis.

2. Cotton stalks (CS) + cattle dung (CD) $(1: 1)$ d.w. basis.

3. $(R S)+(C S)+(C D)(1 / 2: 1 / 2: 1)$ d.w. basis.

4. Mixture (1) + natural additives.

5. Mix. (2) + natural additives.

6. Mix. (3) + natural additives.

7. Mix. (4) + EM.

8. Mix. (5) + EM.

9. Mix. (6) + EM

Natural additives such as natural rocks (rock phosphate and feldspar) as well as vermiculite were mixed with the previous materials of about $2.5 \%$ of total pile's weight; sulfur was also added with a percentage $1 \%$ of total pile's weight. Finally, one liter of effective microorganisms (EM) solution was added. (EM) has been described as a multi-culture of coexisting aerobic and anaerobic beneficial microorganisms. The main species involved in EM include: (Lactic acid bacteria, Photosynthetic bacteria, Yeasts, Actinomycetes and Fermenting fungi) (Higa and Parr, 1994).

In all previous compost piles the moisture content was adjusted to about $60 \%$ of water holding capacity (WHC). The composting process was allowed to continue for 12 weeks, including maturation period. The piles were turned manually for aeration at 2, 4, 8 weeks of composting time.

2. Chemical and physical analyses

Compost samples were collected for analyses after 2, 4, 8 and 12 weeks. The moisture content was determined according to the method described by Black et al.(1965). pH and EC were determined in the compost water extract $(1: 10)$ using a glass electrode $\mathrm{pH}$ meter (Orion Expandable ion analyzer EA920) for $\mathrm{pH}$ (Jodice et al., 1982) and using EC meter, ICM model 71150 for EC according to (Richards, 1954). Soluble nitrogen forms $\left(\mathrm{NH}_{4}{ }^{+}-\mathrm{N}\right.$ and $\mathrm{NO}_{3}{ }^{-} \mathrm{N}$ ) were measured by the method outlined by (Page et al., 1982). Organic matter (OM) content was determined by glowing the dried compost samples at $550^{\circ} \mathrm{C}$ up to a constant weight as described by Black et al.(1965) and organic carbon (OC) was calculated by multiplying (OM) by $58 \%$. Kjeldahl digestion method described by Jackson (1973) was used for determination of the total nitrogen (TN) in compost samples. Available phosphorus and potassium in compost samples were extracted by ammonium-bicarbonate-DTPA solution according to (Soltanpour and Schwab, 1977) and measured using spectrophotometer as described by Troug and Mayer (1949). All the data obtained were statistically analyzed according to the procedures outlined by Gomez and Gomez (1984). And the mean values were compared at the $5 \%$ level of significance by using the least significant difference (L.S.D) test. 
Dora, M.D. et al.

Table (1): Main characteristics of the used agricultural wastes and natural rocks

\begin{tabular}{|c|c|c|c|c|c|}
\hline \multirow{2}{*}{$\begin{array}{c}\text { Physico-chemical } \\
\text { characteristics }\end{array}$} & \multicolumn{3}{|c|}{ Waste type } & \multicolumn{2}{c|}{ Natural rocks } \\
\cline { 2 - 6 } & Rice straw & $\begin{array}{c}\text { Cotton } \\
\text { stalk }\end{array}$ & Cattle dung & $\begin{array}{c}\text { Rock } \\
\text { phosphate }\end{array}$ & Feldspar \\
\hline Bulk density $\left(\mathrm{Kg} / \mathrm{m}^{3}\right)$ & 77 & 125 & 500 & -- & -- \\
\hline $\mathrm{PH}(1: 10)$ & 6.73 & 6.78 & 8.70 & 7.15 & 8.33 \\
\hline $\mathrm{EC}(1: 10) \mathrm{dS} / \mathrm{m}$ & 6.00 & 4.16 & 2.09 & 4.10 & 6.15 \\
\hline Moisture content \% & 11.3 & 10.8 & 66.7 & 2.05 & 1.12 \\
\hline $\mathrm{NH}_{4}^{+}(\mathrm{ppm})$ & 197.8 & 20.3 & 557.5 & -- & -- \\
\hline $\mathrm{NO}_{3}^{-}(\mathrm{ppm})$ & 364.5 & 25.4 & 0.0 & -- & -- \\
\hline $\mathrm{TN} \%$ & 0.9 & 1.2 & 1.8 & -- & -- \\
\hline $\mathrm{OM} \%$ & 82.68 & 92.05 & 78.63 & -- & -- \\
\hline $\mathrm{OC} \%$ & 47.95 & 53.39 & 45.60 & -- & -- \\
\hline $\mathrm{C} / \mathrm{N} \mathrm{ratio}$ & $53: 1$ & $45: 1$ & $25: 1$ & -- & -- \\
\hline Ash \% & 17.32 & 7.95 & 21.37 & -- & -- \\
\hline T.P \% & 0.05 & 0.20 & 0.27 & 17.1 & 0.05 \\
\hline T.K \% & 0.33 & 0.53 & 1.78 & 0.35 & 11.0 \\
\hline
\end{tabular}

\section{Microbial determinations}

Numbers of some microbial groups were determined; Salmonella \& Shigella microorganisms were counted on (SS) agar medium (Difco, 1977) and were recognized with black centered colonies. (Bunt and Rovira, 1955) modified by Abdel-Hafez (1966) was used for counting the phosphate dissolving bacteria which were readily detected by clear zones around the colonies after incubation at $30^{\circ} \mathrm{C}$ for 48 hours. (Subba Rao, 1982) and nitrifying bacteria medium (Black et al., 1965) were used for counting both ammonifiers and nitrifiers, respectively.

\section{RESULTS AND DISCUSSION}

\section{Physical and chemical changes during composting process:}

Changes in the different parameters during composting of agricultural wastes are presented in table (2). It is seen that initial $\mathrm{pH}$ values of the composted materials were in the alkaline range (around 8). By the time, general decrease in $\mathrm{pH}$ values was observed as organic acids released at the first stages of composting; then, they gradually increased towards the last week of the composting time. This was true for mixtures 1,2 and 3 . While $\mathrm{pH}$ values in the amended mixtures $(4,5,6,7,8$ and 9) extended in neutral or slightly acidic till the end of composting. The rate of decrease in $\mathrm{pH}$ values in the amended piles was higher than in the unamended ones. The subsequent increase in $\mathrm{pH}$ may be attributed to the metabolic degradation of the organic acids and/or due to the intensive proteolysis liberating ammonia compound (Faure and Deschamps, 1991). The composting materials showed a gradual increase in EC values until the end of composting to reach values between 4.25 and $5.17 \mathrm{dS} / \mathrm{m}$. These results are in line with those of Allam (2005) and Sohsah (2008).

Total nitrogen (TN) of different organic wastes increased gradually throughout the composting period. This increase seems to be in the range $1.23 \%$ and $1.50 \%$ after 12 weeks of composting. These increases may be due 
to the concentration effect caused by the decomposition of organic carbon compounds which reduced the weight of the composting mass (Viel et al., 1987). In this respect, ammonium concentrations of the compost piles at the beginning ranged between 370 and $760 \mathrm{ppm}$ in all treatments, and then it increased to maximum levels during the thermophilic phase and decreased to low levels at the end of composting. Meanwhile, the $\mathrm{NO}_{3}-\mathrm{N}$ concentrations were very low at the beginning, but by proceeding of composting, $\mathrm{NO}_{3}-\mathrm{N}$ increased due to nitrification process indicating that the decrease of $\mathrm{NH}_{4}-\mathrm{N}$ was associated with significant increase in $\mathrm{NO}_{3}-\mathrm{N}$, where the increase in the rate of nitrification led to a high concentration of $\mathrm{NO}_{3}-\mathrm{N}$. Morisaki et al. (1989) reported that little nitrification occurred under thermophilic conditions, since high temperature and excessive amount of ammonia reduced the activity and growth of nitrifying bacteria. Maximal level of nitrate was recorded at the last week of composting; amended piles have recorded levels of nitrate greater than unamended ones and compost mix. (9) showed the maximum value (350 ppm). These results are in harmony with those obtained by Wong et al. (2001) and Allam (2005).

Data also showed that compost contained high concentrations of organic matter at the initial stage of composting. As composting progressed, these concentrations decreased significantly which occurred mainly during the active phase (thermophilic), causing by mineralization and humification (Bustamante et al., 2008 and Auldry et al., 2009). Decomposition rate of the organic matter was strongly influenced by the mixture compositions as well as additives used (Table 2). While the presence of natural rocks induced relatively high values of decomposition rates in organic matter 19.54, 16.43 and $17.32 \mathrm{~g} / \mathrm{kg} /$ day after one month, these values increased to $20.27,18.70$ and $20.44 \mathrm{~g} / \mathrm{kg} / \mathrm{day}$ with EM addition. These results agreed with the observation of Gautam et al. (2009) who reported that the enrichment of compost with natural additives increased the decomposition rate, which may be due to the high available content of nutrients essential to increase the biological activity.

The $\mathrm{C} / \mathrm{N}$ ratio is one of the main characteristics that limit the suitability of the composting process. Here, $\mathrm{C} / \mathrm{N}$ ratios for the composted materials narrowed from around 30:1 at the beginning to the values between 15: 1 and 22: 1 after 12 weeks. This narrowing mainly may be due to the losses of organic-C as carbon dioxide $\mathrm{CO}_{2}$ and increase of total-N (Goyal, 2005 and Kamolmanit and Reungsang, 2006). The statistical analysis emphasized that there is a significant difference between treatments. the ratio reached to around 20:1 after 12 weeks for composts 1,2 and 3 and after 8 weeks when natural additives were added to mixtures 4,5 and 6 . Moreover, addition of $\mathrm{EM}$ and natural additives together maximized the narrowing of $\mathrm{C} / \mathrm{N}$ ratio to $19.51: 1,21.24: 1$ and $18.70: 1$ in composts 7,8 and 9 , respectively at the $8^{\text {th }}$ week comparing with its negative at the same interval $(20.10: 1,21.87: 1$ and 18.52:1) for composts 4,5 and 6. 
Dora, M.D. et al.

Table (2): Chemical analyses of the organic wastes mixtures at different composting periods

\begin{tabular}{|c|c|c|c|c|c|c|c|c|c|c|}
\hline $\begin{array}{l}\text { Periods } \\
\text { (weeks) }\end{array}$ & $\begin{array}{c}\text { Organic } \\
\text { carbon } \\
\%\end{array}$ & \begin{tabular}{|l|}
$\begin{array}{r}\text { So } \\
\text { nitrog }\end{array}$ \\
$\mathrm{NH}^{+}{ }_{4}$ \\
\end{tabular} & $\begin{array}{l}\text { uble } \\
\text { n (ppm) } \\
\mathrm{NO}_{3}^{-}\end{array}$ & $\begin{array}{l}\text { Total } \\
\mathbf{N} \%\end{array}$ & $\begin{array}{l}\mathrm{C} / \mathrm{N} \\
\text { ratio }\end{array}$ & $\underset{(1: 10)}{\mathrm{pH}}$ & $\begin{array}{c}E C(1: 10) \\
(d S / m)\end{array}$ & $\begin{array}{c}\text { Decomposi } \\
\text { tion rate } \\
\text { (g/kg/day) }\end{array}$ & $\begin{array}{l}\text { Available } \\
\text {-P (ppm) }\end{array}$ & $\begin{array}{c}\text { Available- } \\
\text { K (ppm) }\end{array}$ \\
\hline \multicolumn{11}{|c|}{ Mixture 1 (Rice straw + cattle dung) } \\
\hline 0 & 36.06 & 406 & 22 & 1.04 & 34.67 & 8.21 & 2.43 & --- & 89 & 78 \\
\hline 2 & 35.18 & 813 & 18 & 1.09 & 32.28 & 7.57 & 2.98 & 7.32 & 119 & 100 \\
\hline 4 & 32.10 & 573 & 12 & 1.15 & 27.91 & 7.75 & 3.19 & 16.02 & 197 & 125 \\
\hline 8 & 29.70 & 230 & 79 & 1.24 & 23.95 & 8.07 & 4.71 & 8.75 & 215 & 165 \\
\hline 12 & 27.91 & 78 & 196 & 1.30 & 21.47 & 8.11 & 4.90 & 4.61 & 213 & 180 \\
\hline \multicolumn{11}{|c|}{ Mix. 2 (Cotton stalk + cattle dung) } \\
\hline 0 & 39.71 & 491 & 30 & 1.21 & 32.82 & 8.12 & 1.43 & --- & 93 & 83 \\
\hline 2 & 38.77 & 922 & 21 & 1.28 & 30.29 & 7.60 & 1.86 & 6.77 & 127 & 109 \\
\hline 4 & 34.92 & 391 & 10 & 1.35 & 25.87 & 7.79 & 3.25 & 16.62 & 181 & 133 \\
\hline 8 & 31.59 & 189 & 166 & 1.40 & 22.56 & 7.96 & 3.98 & 8.94 & 210 & 174 \\
\hline 12 & 29.16 & 80 & 212 & 1.44 & 20.25 & 8.07 & 4.25 & 6.30 & 225 & 195 \\
\hline \multicolumn{11}{|c|}{ Mix. 3 (Rice straw + cotton stalk + cattle dung) } \\
\hline 0 & 36.41 & 450 & 35 & 1.08 & 33.71 & 8.09 & 1.52 & --- & 98 & 91 \\
\hline 2 & 35.01 & 835 & 14 & 1.11 & 31.54 & 7.72 & 2.10 & 8.75 & 135 & 115 \\
\hline 4 & 32.37 & 313 & 20 & 1.20 & 26.98 & 7.80 & 3.44 & 16.53 & 150 & 157 \\
\hline 8 & 29.41 & 211 & 150 & 1.30 & 22.62 & 7.99 & 3.87 & 8.52 & 294 & 200 \\
\hline 12 & 27.81 & 63 & 202 & 1.36 & 20.45 & 8.02 & 4.31 & 4.79 & 310 & 210 \\
\hline \multicolumn{11}{|c|}{ Mix. 4 (Mix. $1+$ natural additives) } \\
\hline 0 & 35.99 & 760 & 45 & 1.04 & 34.61 & 8.09 & 2.50 & -- & 101 & 85 \\
\hline 2 & 35.35 & 729 & 34 & 1.08 & 32.73 & 7.86 & 2.92 & 7.94 & 215 & 101 \\
\hline 4 & 29.35 & 315 & 13 & 1.19 & 24.66 & 7.42 & 3.15 & 19.54 & 397 & 218 \\
\hline 8 & 25.33 & 280 & 183 & 1.26 & 20.10 & 7.20 & 4.00 & 11.23 & 543 & 300 \\
\hline 12 & 20.96 & 88 & 315 & 1.30 & 16.12 & 6.98 & 4.66 & 8.30 & 630 & 398 \\
\hline \multicolumn{11}{|c|}{ Mix. 5 (Mix. $2+$ natural additives) } \\
\hline 0 & 39.53 & 405 & 36 & 1.20 & 32.94 & 8.03 & 1.22 & --- & 99 & 93 \\
\hline 2 & 38.74 & 841 & 14 & 1.25 & 30.99 & 7.78 & 1.83 & 7.72 & 225 & 115 \\
\hline 4 & 35.18 & 450 & 10 & 1.30 & 27.06 & 7.35 & 2.90 & 16.43 & 410 & 224 \\
\hline 8 & 31.05 & 228 & 177 & 1.42 & 21.87 & 7.30 & 3.76 & 9.95 & 550 & 315 \\
\hline 12 & 26.12 & 57 & 295 & 1.50 & 17.41 & 7.05 & 4.50 & 7.59 & 685 & 400 \\
\hline \multicolumn{11}{|c|}{ Mix. 6 (Mix. 3 + natural additives) } \\
\hline 0 & 35.03 & 506 & 30 & 1.03 & 34.01 & 8.11 & 1.35 & --- & 110 & 98 \\
\hline 2 & 33.34 & 690 & 18 & 1.11 & 30.04 & 7.79 & 2.06 & 10.39 & 230 & 121 \\
\hline 4 & 29.71 & 318 & 13 & 1.20 & 24.76 & 7.61 & 3.05 & 17.32 & 390 & 230 \\
\hline 8 & 25.00 & 125 & 200 & 1.35 & 18.52 & 7.21 & 4.06 & 11.19 & 568 & 325 \\
\hline 12 & 20.78 & 61 & 320 & 1.37 & 15.17 & 7.03 & 4.37 & 8.09 & 710 & 417 \\
\hline \multicolumn{11}{|c|}{ Mix. 7 (Mix. $4+$ EM) } \\
\hline 0 & 35.60 & 370 & 25 & 1.04 & 34.27 & 8.25 & 2.05 & --- & 102 & 97 \\
\hline 2 & 33.52 & 715 & 19 & 1.12 & 29.93 & 7.56 & 2.97 & 12.15 & 300 & 120 \\
\hline 4 & 28.50 & 466 & 24 & 1.18 & 24.15 & 7.40 & 3.43 & 20.27 & 493 & 295 \\
\hline 8 & 23.41 & 215 & 210 & 1.20 & 19.51 & 7.05 & 4.25 & 11.53 & 678 & 467 \\
\hline 12 & 20.73 & 74 & 330 & 1.23 & 16.85 & 6.90 & 4.91 & 6.60 & 865 & 513 \\
\hline \multicolumn{11}{|c|}{ Mix. 8 (Mix. 5 + EM) } \\
\hline 0 & 38.35 & 471 & 42 & 1.19 & 32.28 & 8.18 & 1.19 & -- & 112 & 98 \\
\hline 2 & 37.36 & 821 & 30 & 1.23 & 30.37 & 7.58 & 1.77 & 9.11 & 315 & 124 \\
\hline 4 & 33.01 & 391 & 11 & 1.29 & 25.59 & 7.31 & 3.27 & 18.70 & 519 & 300 \\
\hline 8 & 27.82 & 220 & 115 & 1.31 & 21.24 & 7.09 & 4.90 & 10.93 & 760 & 480 \\
\hline 12 & 23.07 & 57 & 288 & 1.35 & 17.09 & 6.83 & 5.17 & 7.57 & 901 & 521 \\
\hline \multicolumn{11}{|c|}{ Mix. 9 (Mix. 6+EM) } \\
\hline 0 & 34.81 & 386 & 40 & 1.04 & 33.47 & 8.06 & 1.38 & --- & 119 & 100 \\
\hline 2 & 32.97 & 928 & 23 & 1.17 & 28.18 & 7.43 & 2.05 & 11.99 & 325 & 135 \\
\hline 4 & 28.32 & 429 & 15 & 1.21 & 23.40 & 7.32 & 3.41 & 20.44 & 544 & 314 \\
\hline 8 & 24.12 & 228 & 203 & 1.29 & 18.70 & 7.00 & 4.88 & 10.68 & 782 & 471 \\
\hline 12 & 19.73 & 66 & 350 & 1.33 & 14.83 & 6.80 & 5.00 & 8.94 & 920 & 530 \\
\hline \multicolumn{5}{|c|}{$\begin{array}{l}\text { L.S.D. at }(0.05) \\
\text { For organic carbon } \\
\text { Treatments }=0.76 \\
\text { Periods }=0.56 \\
\text { Interaction }=1.69\end{array}$} & \multicolumn{4}{|c|}{$\begin{array}{c}\text { available-P } \\
0.73 \\
0.55 \\
1.64\end{array}$} & \multicolumn{2}{|c|}{$\begin{array}{c}\text { available-K } \\
6.28 \\
4.68 \\
14.05\end{array}$} \\
\hline
\end{tabular}


This could be explained by the positive action of rocks and EM addition in stimulating decomposition that leads to further decreases in $\mathrm{C} / \mathrm{N}$ ratio, and hence, shortening of composting time. Moreover, mixtures of rice straw showed reduction in $\mathrm{C} / \mathrm{N}$ ratio more than those contained cotton stalk in separate, however mixing them in ratio (1:1) maximized the reduction in $\mathrm{C} / \mathrm{N}$ ratio. Similar findings were noted by Estefanous (2003); El-Haggar et al. ( 2004) and Lela (2005). Ali (2001) explained the slow rate of decomposition in cotton stalks compost compared to those of rice straw by the presence of high relatively amount of lignin.

In respect of available phosphorus and potassium changes during composting process, Data in table (2) showed that nutrients availability was strongly influenced by the decomposition period, type of raw materials and additives used. Concentrations of available- $\mathrm{P}$ and $\mathrm{K}$ gave a gradual increase during the 12 weeks to reach their maximum at the end of composting; this increase was in the range 213 - 920 ppm for available-P and $180-530 \mathrm{ppm}$ for potassium. It was noticed that increasing of $P$ and $K$ availability was maximized in cases of combining rice straw with cotton stalk at ratio of $1: 1(\mathrm{w} / \mathrm{w})$ as compared to composting each of them separately. Among all different treatments, the conjugation of natural additives and effective microorganisms (EM) gave the highest concentrations of phosphorus (920 ppm) and potassium (530 ppm). These results suggest the beneficial effect of such amendments on nutrients releasing and on increasing content of soluble ions which becomes more available to plants. Many investigators have confirmed the nutrients dissolution during composting process (Zayed and Abdel-Motaal, 2005 and Ebrahim, 2006).

Changes in microbial populations during composting process:

Many factors determine the microbial community during composting. Under aerobic conditions, temperature is the major factor that determines the types of microorganisms, species diversity, and the rate of metabolic activities (Hassen et al., 2001).

Survival of pathogenic microorganisms (Salmonella and Shigella):

One of the main purposes of composting was to eliminate the pathogenic microorganisms and to avoid a later recontamination of wastes (Venglovsky et al., 2005). Effects of composting on the survival of Salmonella \& Shigella microorganisms are presented in table (3). Salmonella and Shigella were not detected in most of the mixtures after 8 weeks and completely disappeared from compost after 12 weeks suggesting the highest degree of sanitation. Many workers confirmed the decrease in pathogenic microorganisms by the time of composting (Hassen et al., 2001; Pourcher et al., 2005 and Saidi et al., 2008). In fact, auto-sterilization induced by relatively high temperatures during composting caused a significant change in bacterial communities (Hassen et al., 2001). Moreover, the antagonistic effect of other microorganisms is involved in the inactivation of pathogens as found by Nell et al. (1983) and Stentiford et al. (1984).

Phosphate dissolving bacteria:

Data illustrated in Table (3) showed a general increase in counts of phosphate dissolving bacteria throughout the composting process. However, reduction in their population accompanied the thermophilic phase (4 weeks), 


\section{Dora, M.D. et al.}

followed by increase in mesophilic phase till the end of composting period (12 weeks). Application of natural amendments and effective microorganisms (EM) seems to be accelerator for the multiplication of phosphate dissolving bacteria in compost, where the highest counts in the amended mixtures were in the range of $58 \times 10^{5}$ to $132 \times 10^{5} \mathrm{cfu} / \mathrm{g}$ of d.w. These results were in accordance with the findings of Abdel-Motaal (2004) and Ebrahim (2006).

Table (3): Changes in some microbial groups during composting process

\begin{tabular}{|c|c|c|c|c|c|}
\hline $\begin{array}{ll}\text { Composts } & \text { Periods (weeks) } \\
\end{array}$ & Initial & 2 weeks & 4 weeks & 8 weeks & 12 weeks \\
\hline \multicolumn{6}{|c|}{ Salmonella \& Shigella $\times 10^{1} \mathrm{cfu} / \mathrm{g}$} \\
\hline 1. Rice straw + cattle dung & 500 & 65 & 40 & 6 & nd \\
\hline 2. Cotton stalk + cattle dung & 620 & 50 & 35 & 7 & nd \\
\hline 3. Rice straw + cotton stalk + cattle dung & 490 & 44 & 25 & nd & nd \\
\hline 4. Compost $(1)+$ natural additives & 530 & 55 & 25 & nd & nd \\
\hline 5. Comp. (2) + natural additives & 580 & 46 & 20 & 3 & nd \\
\hline 6. Comp. (3) + natural additives & 600 & 45 & 18 & nd & nd \\
\hline 7. Comp. (4) +EM & 450 & 34 & 10 & nd & nd \\
\hline 8. Comp. (5) +EM & 420 & 37 & 15 & nd & nd \\
\hline 9. Comp. (6) +EM & 530 & 20 & 9 & nd & nd \\
\hline \multicolumn{6}{|c|}{ Ammonifying bacteria $\times 10^{3} \mathrm{cfu} / \mathrm{g}$} \\
\hline 1. Rice straw + cattle dung & 89 & 320 & 192 & 41 & 9 \\
\hline 2. Cotton stalk + cattle dung & 100 & 383 & 160 & 55 & 25 \\
\hline 3. Rice straw + cotton stalk + cattle dung & 90 & 235 & 96 & 44 & 12 \\
\hline 4. Comp. (1) + natural additives & 95 & 220 & 92 & 60 & 26 \\
\hline 5. Comp. (2) + natural additives & 80 & 330 & 125 & 45 & 14 \\
\hline 6. Comp. (3) + natural additives & 120 & 245 & 96 & 22 & 11 \\
\hline 7. Comp. (4) +EM & 92 & 254 & 172 & 50 & 21 \\
\hline 8. Comp. (5) +EM & 110 & 345 & 98 & 33 & 16 \\
\hline 9. Comp. (6) +EM & 82 & 390 & 115 & 60 & 35 \\
\hline \multicolumn{6}{|c|}{ Nitrifying bacteria $\times 10^{3} \mathrm{cfu} / \mathrm{g}$} \\
\hline 1. Rice straw + cattle dung & 1.9 & 0.9 & 0.2 & 13.1 & 17.0 \\
\hline 2. Cotton stalk + cattle dung & 3.3 & 2.0 & 0.5 & 11.0 & 25.2 \\
\hline 3. Rice straw + cotton stalk + cattle dung & 2.4 & 1.1 & 0.2 & 12.7 & 21.0 \\
\hline 4. Comp. (1) + natural additives & 2.5 & 1.0 & 0.1 & 12.0 & 26.0 \\
\hline 5. Comp. (2) + natural additives & 2.4 & 1.0 & 0.3 & 16.2 & 24.5 \\
\hline 6. Comp. (3) + natural additives & 3.0 & 1.2 & 0.2 & 14.0 & 28.3 \\
\hline 7. Comp. (4) +EM & 3.2 & 0.9 & 0.2 & 15.6 & 25.0 \\
\hline 8. Comp. (5) +EM & 2.6 & 1.3 & 0.3 & 16.8 & 27.5 \\
\hline 9. Comp. (6) +EM & 1.8 & 0.8 & 0.1 & 17.3 & 30.3 \\
\hline \multicolumn{6}{|c|}{ Phosphate dissolving bacteria $\times 10^{5} \mathrm{cfu} / \mathrm{g}$} \\
\hline 1. Rice straw + cattle dung & 12 & 10 & 9 & 55 & 80 \\
\hline 2. Cotton stalk + cattle dung & 19 & 15 & 13 & 46 & 58 \\
\hline 3. Rice straw + cotton stalk + cattle dung & 21 & 9 & 10 & 38 & 78 \\
\hline 4. Comp. (1) + natural additives & 17 & 12 & 7 & 31 & 73 \\
\hline 5. Comp. (2) + natural additives & 25 & 15 & 16 & 56 & 92 \\
\hline 6. Comp. (3) + natural additives & 13 & 6 & 6 & 52 & 98 \\
\hline 7. Comp. (4) +EM & 24 & 21 & 18 & 95 & 125 \\
\hline 8. Comp. (5) +EM & 33 & 12 & 10 & 92 & 110 \\
\hline 9. Comp. (6) +EM & 39 & 27 & 12 & 105 & 132 \\
\hline
\end{tabular}

nd : not detected.

cfu : colony forming unit. 


\section{Ammonfying and nitrifying bacteria:}

Counts of ammonifiers and nitrifiers throughout composting period are presented in table (3). It is seen that the counts of ammonifying bacteria increased and reached to its maximum numbers after two weeks, then declined till the end of composting period. This trend showed a reasonable explanation of ammonical- $\mathrm{N}$ behaviour throughout composting process. The detected numbers of nitrifiers were lower than those of ammonifiers. A decrease in counts of nitrifying bacteria accompanied thermophilic phase, then it gradually increased till the end of composting. The high densities of ammonifying bacteria, especially in the ammended treatments, which reached to maximum levels after two weeks of composting, might indicate a high ammonification activity and release of ammonia which subsequently enhance the multiplication of nitrifiers that extended to the end of composting. The decrease in ammonifiers after two weeks numbers might also indicate less ammonification activity. Therefore, nitrifiers showed higher numbers at the end of composting process. These results are in agreement with the fact that fresh materials inhibit nitrification. These results are in harmony with those of Gazi et al. (2007) who found that through composting of green wastes nitrifying bacteria only appeared when the temperature declined, as these organisms are not thermotolerant.

\section{REFERENCES}

Abdel-Hafez, A.M. (1966). Some studies on acid producing microorganisms in soil and rhizosphere with special reference to phosphate dissolvers. Ph.D. Thesis, Faculty of Agriculture, Ain Shams University, Egypt.

Abdel-Motaal, Heba, M. (2004). Production of organic fertilizer enriched with phosphorus from some agricultural wastes mixed with rock phosphate. M.Sc Thesis, Department of Agricultural Microbiology, Faculty of Agric., Minia University.

Ali, Laila, K.M. (2001). Use of improved organic fertilizers as nutrients sources. Ph.D. Thesis, Fac. Agric., Ain Shams, Univ., Egypt.

Allam, E.H. (2005). Studies on recycling of some agricultural environment wastes for organic fertilizers production. Ph.D. Thesis, Dept. soils, fac. Agric., Benha Univ., Egypt.

Auldry, C.P., Ahmed, O.H., Nik, A.M., Mohammad Nasir, H., and Jewan, M. (2009). Production of potassium and calcium hydroxide, compost and humic acid from sago (Metroxylon sagu) waste. American Journal of Environmental Sciences. 5 (5): 664-668.

Black, C.A., Evans, D.O., Enmunger, L.E., White, J.L., Clark, F.E. and Dineure, R.C. (1965). Methods of Soil Analysis II, Chemical and Microbiological properties. American Soc. Agron. Inc. Madison, Wisconsin, USA.

Bunt, J.S. and Rovira, A.D. (1955) Microbiological studies of some subAntarctic soils. J. Soil Sci., 6:119-128. 
Bustamante, M.A., Paredes, C., Marhuenda-Egea, F.C., Pérez-Espinosa, A., Bernal, M.P. and Moral, R. (2008). Co-composting of distillery wastes with animal manures: Carbon and nitrogen transformations in the evaluation of compost stability. Chemosphere. 72: 551-557.

Difco Manual of Dehydrated Culture Media and Reagents. (1977). Microbiological laboratory procedures. Ninth Edition, P. 134. Difco Laboratories, Detroit. Michigan, USA.

Ebrahim, Amal, E.H. (2006). Biodiversity and its role in some biological processes of natural ecosystems. Ph.D. thesis, Dept. Agric. Microbiol. Fac. Agric., Cairo univ., Egypt.

Edwards, C.A. (2002). Assessing the effects of environmental pollutants on soil organisms, communities, processes and ecosystems. Eur. J. soil. Biol., 38: 225- 231.

El-Haggar, S.M., Ali, B.E., Ahmed, S.M., and Hamdy, Mona, M. (2004). Increasing nutrients solubility from some natural rocks during composting of organic wastes. Minia J. Agric. Res. \& Develop., 24 (1): PP. 71-88.

El-Shimi, S.A. (2005). Design and cost analysis of agricultures wastes recycling alternatives for Sinbo village, Gharbiya Governorate. Environmental services for improving water quality management. Report No. 15. International resources group in association with EPIQ II consortium.

Estefanous, A.N. (2003). Amendment of rice straw with rock phosphate and certain microbial inoculants for production of high quality compost. Egypt. J. Appl. Sci., 18: 441-455.

Faure, D. and Deschamps, A.M. (1991). The effect of bacterial inoculation on the initiation of composting grape pulps. Biores. Tech., 37: 235-238.

Gajdos, R. (1992). The use of organic waste materials as organic fertilizersrecycling of plant nutrients. Acta hortic., 302: 325-331.

Gautam, S.P., Bundela, P.S., Pandey, A.K., Jain, R.K., Deo, P.R., Khare, S.K., Awasthi, M.K. and Surendra Sarsaiya. (2009). Biodegradation and recycling of urban solid waste. American J. Environ. Sci. 5 (5): 653-656.

Gazi, A.V., Kyriacou, A., Kotsou, M. and Lasaridi, K.E. (2007). Microbial community dynamics and stability assessment during green waste composting. Global NEST Journal, 9 (1): 35-41.

Gomez, K.A. and Gomez, A.A. (1984). Statistical Procedures for Agricultural Research. $2^{\text {nd }}$ ed. John Wiley \& Sons.

Goyal, S., Dhull, S.K. and Kapoor, K.K. (2005). Chemical and biological changes during composting of different organic wastes and assessment of compost maturiy. Biores. Tech., 96: 1584-1591.

Hassen, A., Belguith, K., Jedidi, N., Cherif, A., Cherif, M. and Boudabous, A. (2001). Microbial characterization during composting of municipal solid waste. Birores. Tech., 80: 217-225. 
Higa, T. and Parr, J.F. (1994). Beneficial and Effective Microorganism for a Sustainable Agriculture and Environment. International Nature Farming Research Center. Atami, Japan, 1994.

Jackson, M.L. (1973). Soil Chemical Analysis. Prentice-Hall of India Private Limited, New Delhi, India.

Jodice, R., Luzzati, A. and Nappi, P. (1982). The influence of organic fertilizers obtained from poplar banks on the correction of iron cholosis of luipinus albus, plant and Soil. 65: 309-317.

Kaloosh, A.A. (1994). Changes in composition of a compost prepared from different organic materials and its effect on vicia faba yield. J. Agric. Sci., Mansoura Univ., 19: 829-836.

Kamolmanit, N. and Reungsang, A. (2006). Effect of carbon to nitrogen ratio on the composting of Cassava pulp with swine manure. J. Water and Environ. Techn., 4 (1): 33-50.

Lela, K.M. (2005). Studies on mixing of bio and organic fertilizers on nutrient availability and crop production. M. Sc. Thesis, Soils and Water Dept., Fac. Agric., Al-Azhar Univ., Egypt.

Morisaki, N., Phae, C.G., Nakasaki, K. and Shoda, M. (1989). Nitrogen transformation during thermophilic composting. Journal of Fermentation and Bioengineering. 67, 57-61.

Nell, J.H., Steer, A.G. and Vanrensburag, P.A.J. (1983). Hygienic quality of sewage sludge compost. Water Sci. Tech., 15 (1): 181-194.

Page, A.L., Miller, R.H. and Keeny, D.R. (1982). Methods of Soil Analysis. Part 2. Soil Sci. Soc. Amer. Inc. Madison, Wisconsin, USA.

Pourcher, A. M., morand, P., picard-Bonnaud, F., Billaudel, S., Monpoeho, S. and Federighi, M. (2005). Decrease of enteric microorganisms from rural sewage sludge during their composting in straw mixture. J. App. Microbiol., 79: 528-539.

Richards, L.A. (1954). Diagnosis and improvement of saline and alkali soil. U.S. Dep. Agric, hand book, No. 60 Gov. print off.

Saidi, N., Cherif, M., Jedidi, N., Mahrouk, M., Fumio, M., Boudabous, A. and Hassen, A. (2008). Evolution of biochemical parameters during composting of various wastes compost. American J. Environ. Sci., 4 (4): 332-341.

Sohsah, M.A. (2008). Microbiological and physiological studies on the sequences of the microbial populations in the organic fertilizer piles undder Egyption conditions. M.Sc. Thesis, Dept. Agric. Botany, Fac. Agric., Al-Azhar Univ. Egypt.

Sharma, S., Mathur, R.C. and Vasudevan, P. (1999). Composting silk warm culture waste. Compost Sci. Util., 7 (2): 74-81.

Soltanpour, P.N. and Schwab, A.P. (1977). A new soil test for simultaneous determination of macro and micro-nutrient in alkaline soils. Commun. Soil Sci. plant Anal., 8: 195-207.

Stentiford, E. I., Mara, D.D. and Tayar, P.L. (1984). Forced aeration composting of domestic refuse and sewage sludge in static piles. Proceeding of a seminar organized by the commission of the European communities held at Brasenose Collegs. Oxford, 19-20 March (1984), p. $42-54$. 


\section{Dora, M.D. et al.}

Subba Rao, N.S. (1982). Advances in Agriculture Microbiology. In: Subba Rao, N.S., editor. "Studies in the Agricultural and Food Science". Butterworth Scientific, London, pp.295-303.

Troug, E. and Mayer, A.H. (1949). Improvements in the Denig's colorimetric method for phosphorus and arsenic. Ind. Eng. Chem. Anal., 1:136-139.

UNDP (United Nations Development Programme) (2005). National Strategy for Environmentally sound Management of Crop Residues .

Venglovsky, J., Sasakova, N., Vargova, M., Pacajova, Z., Placha, I., Petrovsky, M. and Harichova, D. (2005). Evolution of temperature and chemical parameters during composting of pig slurry solid fraction amended with zeolite. Biores. Tech., 96: 181-189.

Viel, M., Sayag, D., Andre, L. (1987). Optimization of agricultural industrial wastes management through in-vessel composting. In: De Bertoldi, M. et al., (Eds.), "Compost: Production, Quality and Use". Elsevier Applied Science, Essex., pp. 230-237.

Wong, J.W.C., Mak, K.F., Chan, N.W., Lam, A., Fang, M., Zhou, L.X., and Wu, Q.T. (2001). Co-composting of soybean residues and leaves in Hong Kong. Biores. Tech., 76: 99-106.

Zayed, G. and Abdel-Motaal-Heba, M. (2005). Bio-active composts from rice straw enriched with rock phosphate and their effect on the phosphorus nutrition and microbial community in rhizosphere of cowpea. Biores. Tech., 96: 929-935.

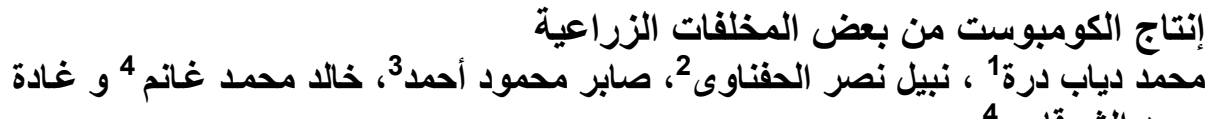

$$
\begin{aligned}
& \text { سعيد الثرقاوى } 4
\end{aligned}
$$

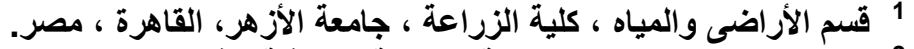

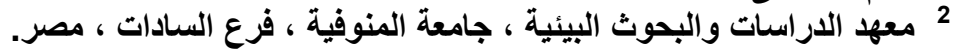

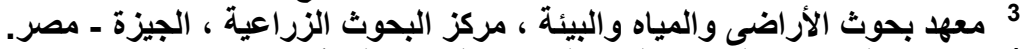

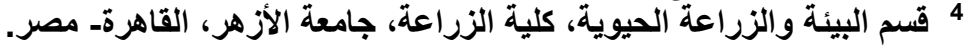

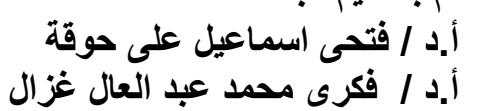


J. Agric. Chem. and Biotech., Mansoura Univ. Vol.(12), December, 2010 